\title{
Lingkungan dalam Pembelajaran Bahasa Indonesia
}

Menurut Mitsuki dan Lai (dalam Ramadhan et al, 2019), di seluruh dunia, setiap orang menghadapi masalah lingkungan yang serius, seperti pemanasan global, hujan asam, perusakan lapisan ozon, pencemaran lingkungan, kerusakan alam, dan hilangnya keanekaragaman hayati yang dapat mengancam kehidupan generasi sekarang, terutama generasi mendatang. Salah satu masalah yang dihadapi Indonesia dari masa ke masa yaitu masalah kebersihan, terutama masalah sampah. Kesadaran masyarakat Indonesia akan pentingnya membuang sampah pada tempatnya masih terbilang sangat rendah. Masyarakat sering membuang sampah sembarangan, seperti membuang sampah di sungai, jalanan, atau di tempat-tempat lain. Kebanyakaan masyarakat menganggap biasa permasalahan mengenai sampah, inilah yang menjadi penyebab utama meningkatnya permasalahan sampah dari tahun ke tahun.

Salah satu masalah kebersihan terjadi di lingkungan perguruan tinggi. Perguruan tinggi atau kampus merupakan lembaga formal yang berfungsi membantu dalam memberikan pengetahuan, keterampilan dan sikap kepada mahasiswa. Kebersihan lingkungan merupakan komponen yang berpengaruh dalam pelaksanakan aktifitas belajar mengajar. Kebersihan juga dapat menunjang jalannya kegiatan belajar mengajar di kampus. Namun, pada kenyataannya masih minimnya tingkat kesadaran akan pentingnya menjaga kebersihan lingkungan kampus, seperti membuang sampah sembarangan meskipun telah disediakan tempat sampah. Berdasarkan hasil penelitian penulis 73,3\% mahasiswa menyatakan sangat setuju bahwa dosen menyadarkan mahasiswa untuk menjaga lingkungan dan selebihnya 27,7\% siswa menyatakan setuju, namun masih banyak mahasiswa yang belum sadar akan menjaga lingkungan. Dosen memberikan teguran kepada mahasiswa jika membuang sampah sembarangan 53,8\% menyatakan sangat setuju, 38,5\% menyatakan setuju dan 7,7\% mahasiswa kurang setuju, tetapi mahasiswa tetap tidak jera jika diberi teguran oleh dosennya. Dosen menjadi contoh figur yang baik dalam menjaga kelestarian kampus 63,1\% menyatakan sangat setuju, 33,8\% setuju dan 3,1\% kurang setuju namun masih ada mahasiswa yang kurang setuju jika dosen menjadi contoh dalam menjaga kelestarian kampus. Pada kenyataan nya masih banyak mahasiswa yang tidak peduli akan sampah yang berserakan sesuai hasil penelitian 44,6\% sangat setuju 53,8\% setuju dan 1,5\% kurang setuju jika mahasiswa melihat sampah dia akan mengambil dan memasukkannya ke dalam tempat sampah. Mahasiswa mampu menegur mahasiswa lainnya ketika membuang sampah sembarang terbukti pada hasil penelitian $60 \%$ sangat setuju 38,5\% setuju dan ada $1,5 \%$ kurang setuju.

Sampah yang paling sering kita temui yaitu sampah plastik dan botol minuman, menurut hasil penelitian $65,2 \%$ menyatakan setuju membawa tempat minum untuk mengurangi sampah botol minuman 28,8\% menyatakan setuju, 4,5\% menyatakan kurang setuju dan 1,5\% menyatakan setuju. Jadi, inilah salah satu penyebab banyaknya sampah botol minuman atau kaleng bekas. Padahal dengan cara membwa botol minuman kita akan menghemat untuk tidak membeli dan meminim sampah botol atau kaleng bekas minuman.

Untuk mengatasi permasalahan kerusakan lingkungan, diperlukan sebuah tindakan yang serius untuk mencegah kerusakan lingkungan yang semakin memburuk. Menurut Nazarenko dan Bergman (dalam Ramadhan et al, 2019), untuk mengatasi ini, guru memainkan peran penting 
dalam mengajar pendidikan lingkungan dan menumbuhkan kesadaran siswa tentang lingkungan. Menurut Buldur dan Omeroglu (dalam Ramadhan et al, 2019), pendidikan lingkungan penting untuk meningkatkan sikap dan kesadaran siswa terhadap lingkungan. Pendidikan lingkungan harus dirancang untuk berkontribusi pada pengembangan kognitif, emosional, linguistik dan psikomotor siswa, dan memungkinkan mereka untuk mengembangkan sikap positif terhadap lingkungan Selain itu, guru juga harus mengembangkan kemampuan siswa untuk memahami, mengkritik, dan berpartisipasi secara rasional dalam setiap wacana tentang masalah lingkungan. Menurut Rivers (dalam Ramadhan et al, 2019), sebagai guru bahasa, kami adalah guru yang paling beruntung, semua mata pelajaran adalah milik kami. Apa pun yang ingin dikomunikasikan oleh siswa kami, apa pun yang ingin mereka baca, adalah materi pelajaran kami. Menurut Hauchild, Poltavthenko dan Stoller(dalam Ramadhan et al, 2019), guru bahasa berada dalam posisi unik untuk mempromosikan kesadaran lingkungan. Seperti pada hasil penelitian 39,4\% menyatakan sangat setuju 56,1\% menyatakan setuju dan 4,5\% kurang setuju jika dosen atau guru menerapkan metode persuasi dalam menjaga kebersihan lingkungan.

Berdasarkan hasil kajian dan penelitian yang dilakukan penulis, dapat disimpulkan bahwasannya lembaga pendidikan memiliki peran penting dalam proses penanaman pendidikan wawasan lingkungan kepada peserta didik, dan pendidik senantiasa menjadi penyambung proses nilai-nilai positif berbasis lingkungan kepada peserta didik. Kemudian pendidikan wawasan lingkungan dapat dintegrasikan kedalam subyek mata pelajaran dan mata kuliah bahasa Indonesia untuk memberikan pengetahuan dan ketrampilan komprehensif dalam menjaga lingkungan. Tulisan ini digunakan sebagai bahan evaluasi bersama untuk penulis, pembaca dan khalayak luas untuk menjaga lingkungan bersama demi terjaganya kelestarian lingkungan.

\section{Daftar Rujukan}

Bergman, B.G. (2016). Assessing impacts of locally designed environmental education projects on students' environmental attitudes, awareness, and intention to act Environmental Education Reseach 22(4) 480-503

Buldur, A. and Ömeroglu, E. (2018). An examination of the relationship between pre-school children's and their teacher' attitute and awareness towards the environment Journal of Education and Learning 7(2) 221-9

Hauchild, S., Poltavthenko, E. and Stoller, F. L. (2012). Going green: Menging environmental education and language instruction English Teaching Forum Number 2 2-13

Lai, C.S.(2018). A study of fifth graders' environmental learning outcomes in Taipei International Journal of Research in Education and Science 4(1) 252-61

Mitsuki, I. (2017). Beyond the limitations of environmental education in Japan Educational Studies in Japan: International Yearbook Number 11 pp 3-14

Nazarenko, A.V. and Kolesnik, A.I. (2018). Raising environmental awareness of future teachers International Journal of Instruction 11(3) 63-76

Ramadhan, S., Sukma, E., \& Indriyani, V. (2019). Environmental education and disaster mitigation 
through language learning. IOP Conference Series: Earth and Environmental Science, 314.

Rivers, W.(1976). Speaking in many tongues: Essay in foreign language teaching (2nd edition) (Rowley: MA Newbury House) p 96 